\title{
2 \\ The Early Rise of Social Security in China: Ideas and Reforms, 1911-1949
}

\author{
Aiqun $\mathrm{Hu}$
}

\section{Introduction: The Early Rise of Social Ideas and Policies}

Republican Era (1911-1949) was a time of upheaval in Chinese history, but it is less well known that it was also the beginning of the rise in ideas and policies on social security. Social security in China is mostly understood as beginning in the post-1949 era, after the Chinese revolution, with the rise of the People's Republic of China and the retreat of the Guomindang (GMD, the Chinese Nationalist Party or Kuomintang) government to Taiwan. This chapter argues that substantial social security ideas and policies had already made their appearance during the Republican years prior to 1949.

I would like to thank Lutz Leisering, the editor of this volume, for his extensive and detailed comments on the earlier versions of this chapter.

\section{A. $\mathrm{Hu}(\bowtie)$}

Arkansas State University, Jonesboro, AR, USA

e-mail: aiqunhu@astate.edu 
The term "social security" first appeared in the 1935 US Social Security Act. International organisations officially used it in the early 1940s, and it gained wide usage after the Second World War. Social security, a major type of social policy_-defined as state actions via legislation and administration to solve social problems-refers to a combination of social insurance and social assistance or any government programmes providing cash and in-kind benefits to those with inadequate income.

In China, "social security" as an imported term emerged in official documents in 1945. Throughout China's long imperial history, Chinese people mainly relied on the family, clan and neighbourhood for their social security needs. China's imperial state, however, provided temporary famine relief (buangzheng) after disasters and regular poor relief for individuals labelled as "widowers, widows, orphans, elderly without children, and the infirm (guangua gudu fei)" . In the 1900s (the last decade of the Qing rule), the Qing Dynasty set up vagrant workhouses as a new type of poor relief, which soon disintegrated after the fall of the Qing in 1911. The succeeding Republic of China, in its first two chaotic decades under the Beijing government (1911-1927), was able to restore some of the poorhouses and workhouses, as well as issue factory and labour protection laws. In the two decades of GMD rule (1927-1949), the GMD government developed social security ideas and policies, including relief homes and labour insurance in the 1930s, as well as social relief and social insurance in the 1940s.

Historical studies on Republican China were conventionally very critical of the GMD government and attributed its defeat by the Chinese Communist Party (CCP) to corruption, incompetency, and factionalism (Eastman 1984). Recently, revisionist scholarship has treated the GMD government more favourably, concentrating not only on what it achieved in extremely tough circumstances but also on the significance of its achievements for the succeeding People's Republic (Wakeman and Edmonds 2000). In terms of social welfare broadly defined, however, studies predominantly focus on relief for refugees, victims of famines,

\footnotetext{
${ }^{1}$ Elderly men without wives were widowers (guang), elderly women without husbands were widows (gua), elderly people without sons were $d u$, children without fathers were orphans $(g u)$, and disabled persons were the infirm $(f e i)$.
} 
and the poor (MacKinnon 2008; Chen 2012), and they barely pay attention to social insurance and social security (except $\mathrm{Hu} 2015$; Ma 2012, 2014). Some scholars in social sciences have explored the ideational aspects of China's social welfare but treat the ideas as an independent factor (Leung and Nann 1995). In other words, these studies tend to conceive of ideational factors in social policymaking in terms of broad ideas (Hu 2012; Shi 2017; Breman et al. 2019) and neglect more specific ideas, like "social security" or "social questions", and the interactive and formative role of ideas.

The present study attempts to fill this research gap by applying Lutz Leisering's "onion skin model" of social policy ideas (Leisering 2019, chapter 2, 21-63, and chapter 9, 327-330; see also the introduction to this volume). Based on theories of the constructivist sociology of knowledge, this model creatively treats ideas as a multi-layered system that not only interacts with but also co-defines other structural factors. According to this model, social policy ideas consist of four layers plus frames on top of the layers. From the most abstract to the most concrete, each of the four layers is collective social responsibility, social question, social problems, and welfare institutions, and on top of these four layers, there exist "frames" such as "discourses on nation building, development, economy, or world cultural principles, or any other frames" (ibid., 34-35).

According to Leisering, the collective social responsibility layer refers to the state's recognition and assumption of its social responsibility, which is often written in a country's constitution. The social question layer is a generalised recognition of social problems that require state policy remedies. The social problems layer refers to the process of labelling, defining, and theorising social problems and seeking policy remedies. The welfare institutions layer refers to the state's adoption of certain welfare institutions, such as social assistance and social insurance as a response to perceived social problems. Policy frames are broader ideas that can legitimise or negate the adoption of certain social policies (ibid., 327-330).

As an empirical study applying Leisering's ideational model, this chapter reveals that China saw an early rise in social security ideas and institutions in the first half of the twentieth century, which include certain continuities across the 1949 divide between the nationalist and communist regimes. Western imperialism, along with domestic developments, 
led to unprecedented social upheavals in China, which provoked Chinese intellectuals and officials alike to constantly seek a way out to "save the nation" (Zanasi 2006; Fung 2010). These Chinese elites turned to Western social ideas, especially sociological knowledge, to identify social problems and seek relevant social policies to tackle these social problems in the early decades of the twentieth century, especially in the interwar era of the 1920s and 1930s. With the breakout of the Second SinoJapanese War in 1937, the above-mentioned trends were strengthened during the war. In the early 1940s, Chinese elites were attracted to the emerging global idea of universal social security, which led to a significant and intensified period of social policy development in China. This had policy significance for post-war social security programmes, mainly in Taiwan, but also in China in the 1950s.

Although Western social ideas played an important role, this study argues that Republican China, especially the GMD state, emphasised collectivistic rather than individualist notions of social problems and social policy that fit the perceived special Chinese situation, which was viewed as a mixture of such factors as an agrarian society, backward production, an unorganised society that could not prevent foreign oppression, and a deep-rooted tradition of Confucianism as well as Western imperialism. Overall, this study contends that in the entire Republican era, especially under the GMD regime, the social question remained strong, but social policy to respond to the social question was treated as a crucial part of state building based on a combination of reinterpreted Confucianism and Western social ideas. Thus, social policy emphasised not only productivism but also social order and harmony, with the ultimate purpose of advancing China's national interests and achieving wealth, power, and glory for China.

It is helpful to trace the evolution of the official terms used to discuss social security in Republican China, as this ideational study is related to the literature on the conceptual history of social policy (Rodgers 1998; Kettunen and Petersen 2011; Kaufmann 2013; Béland and Petersen 2014). In the last decade of the Qing dynasty, the government maintained the imperial poorhouses or yangji yuan (nurture-relief homes) for "those unable to work". The government also established xiyisuo (workhouses) for vagrants and petty criminals, and a new type of poorhouse, 
jiaoyang yuan (teaching-nurture homes), for "unruly people". These workhouses and poorhouses continued to exist under the Beijing government (1911-1927) but in a disintegrated state (Chen 2012). In Republican China in the 1920s, the Beijing government called for "social insurance" in response to the International Labour Organization's (ILO) request, while the $\mathrm{CCP}$-led labour movement demanded for "social insurance" ( $\mathrm{Hu} 2015)$.

In the first decade of the GMD's rule (1927-1937), a single "relief home" (jiuji yuan) incorporated the functions of all sorts of previous poorhouses and workhouses, while "labour insurance" appeared in the 1931 Constitution. In addition, the term "social relief" referred to a broad range of poor relief, labour insurance, and other types of social welfare in the 1930s, while "social insurance" appeared in scholarly discussions in the 1920s and 1930s. In the 1940s, the GMD state used such terms as "social welfare" and "social insurance", while "social security" began to emerge in official usage in 1945. Furthermore, the content of the term "social relief" in the 1940s shrank to refer to social assistance only as "social insurance" became officially recognised. The CCP also used similar terms, such as social relief, labour insurance, social insurance, and labour protection laws in its documents for areas under its control.

This chapter is divided into five parts. Part one introduces preRepublican China's state relief with a focus on the ideational transition from Confucian benevolence to Western disciplined labour as the baseline for ensuing discussions. Part two analyses the rise of social problems in China and the accompanying Chinese Marxist and non-Marxist concepts, explaining these social problems, mainly in the 1920s. Part three discusses the GMD state's social policy in its first decade (1927-1937), especially poor relief and labour insurance, and argues that the GMD state's social policy, as part of its state-building efforts, emphasised productivist and collectivistic notions of social problems and social policy. Part four focuses on the GMD state's wartime social policy (1937-1945). It argues that the Allied forces' emerging concept of universal social security had a profound impact on the GMD state's social security, but Chinese elites emphasised China's special situation when designing China's social security (both social relief and social insurance) policies. 
Part five concerns itself with the institutionalisation of social security in the post-war era and explores the implications of the GMD state's social security on that of the People's Republic. Meanwhile, parts three to five consider the years under GMD rule, including discussions of social security in the CCP-controlled areas. Finally, the conclusion highlights the major findings.

\section{Social Security in Imperial China: From Benevolence to Disciplined Labour}

Imperial China, largely a unitary state system for over 2000 years, began to provide emergency famine relief during the Han Dynasty (206 BCE -220 CE) and regular poor relief during the Tang Dynasty (618-907 CE), with the majority of people dependent on their families, kin groups, and neighbourhoods for social security. Some scholars even argued for an earlier origin of state famine relief, for example, one scholar contends that the Zhou rulers (1046-256 BCE) established well-managed granaries for famine relief, and granaries existed even in the Xia Dynasty of the sixteenth century BCE (Wang 2002: 153-154). The reason for the early recognition of state responsibility for providing social relief is closely related to China's long-lasting and deeply rooted Confucianism. Confucianism, together with Daoism and Legalism, took shape during the three centuries proceeding the Qin state's unification of China in 221 BCE. These early intellectual schools focused on restoring the social and political order, as centuries of warfare had caused great suffering, chaos and confusion, following the disintegration of the Western Zhou (1045-771 BCE).

Confucianism, however, was established as the state ideology during the Han Dynasty in 136 BCE and was restored during the Song Dynasty (960-1279 CE) as neo-Confucianism, which incorporated many philosophical ideas from Buddhism in the twelfth century. Confucianism thus remained as the state ideology for the rest of Chinese imperial rule and emphasised the value of benevolence (ren), benevolent government (renzheng), familism, and harmony. In terms of familism, the family was 
regarded as a prototype of the state: the family was a mini-state, and the state was an enlarged family. The emperor as the son of heaven was the father of his subjects; thus, the emperor should take care of the well-being of his sons or his subjects (Leung and Nann 1995). Therefore, state relief was regarded as necessary emperor and state benevolence.

In any case, the Han Dynasty established ever-normal granaries (changping cang). These granaries not only aimed to stabilise market grain prices at a "normal" level, which led to the term "ever-normal" but also distributed grains to famine victims in times of disaster. By the Sui and Tang Dynasties (581-907 CE), the state not only inherited the ever-normal granaries but also set up charity granaries ( yi cang) and community granaries (she cang). The government organised charity granaries and collected taxes or donations of grain to redistribute to the poor in times of famine and other disasters, while villages organised and managed community granaries, which collected and distributed grains to the poor for relief purposes. This granary system remained the main state measure for famine and disaster relief throughout imperial history (Will and Wong 1991).

Furthermore, the Chinese imperial state began to provide medical and material relief to the poor during the Tang Dynasty. India-originated Buddhism became so influential that the Tang Dynasty launched a suppression of it in $845 \mathrm{CE}$ and took over the Buddhist medical relief institutions (Cai 2003: 37). These medical relief institutions survived into the succeeding Song Dynasty, which also opened up other types of relief institutions to provide material support to the poor (Wang 2007: 234). The Song poor relief, according to recent scholarship, represented the highest level of development of social policy in Chinese imperial history, surpassing the levels of the succeeding Ming and Qing Dynasties (Sun and Bi 2018; Zhang 2017).

Nonetheless, the succeeding imperial dynasties inherited the poorhouses, which were grouped into four types by the mid-nineteenth century: nurture-relief homes (yang-ji yuan), universal-relief halls ( $p u$-ji tang), soup kitchens (zhou chang), and vagrants' shelters (qi-liu suo). The emperors decreed these poorhouses, which local governments then managed. Local revenue financed the nurture-relief homes and admitted those within the local administration's jurisdiction. They provided food, 
winter clothes and money to the inmates. Unlike the nurture-relief homes, the universal-relief halls did not have stable financial sources because they relied on government subsidies and private donations and investment. As shown by the name, these halls did not have local residency requirements; they not only provided food, winter clothes, and money but also included soup kitchens and other facilities to provide cold water in the summer and warm ginger soup in the winter (Zhang 2012).

After the mid-nineteenth century, however, the Qing government's famine and poor relief declined, as the Qing dynasty's central financial situation rapidly deteriorated due to both internal crisis and Western imperialism. This situation not only provided an opportunity for nongovernmental and non-family-based charities operated by local gentries to play an increasingly important role in social relief in this period (Liang 1997) but also inspired Chinese elites to reform the existing poorhouses based on the "positive" methods used by Western missionaries to manage their charities in China.

In the latter half of the nineteenth century, Western missionaries operated schools and charities to facilitate their missionary activities in China. The Chinese elites viewed the Westerners' methods for running their charities as "positive" because these charities not only provided material support but also taught children how to read and write and the skills they needed for future employment. The elites thus began to introduce these positive methods to reform the declining poorhouses. For instance, the vagrants' shelters, which originally only provided food, clothing, and medicine, began to provide job training to the inmates. The Shanghai vagrants' shelter was one of the first to do so in 1879. The Tianjin guangrentang (a comprehensive charitable institution), which was established in 1878 and followed the model of missionary hospitals, included workshops that required homeless inmates to work (Huang 2011; Wang 2008).

In the 1900s, the above-mentioned trends continued as the Qing government launched new policies, a set of comprehensive political and economic reform measures. Among these reforms was the establishment of handicraft and industrial training centres (gong-yi ju) as part of the policy to develop industry, which coincided with Qing Dynasty's penal system reforms, which established workhouses ( $x i-y i$ suo) based on Japanese 
models. While the training centres gradually declined due to lack of funding, workhouses were widely set up for both criminals and vagrants. The first workhouses included the 1904 Tianjian Criminal Workhouse, the 1905 Tianjin Vagrant Workhouse, and the 1906 Beijing Capital Workhouse for both criminals and non-criminals. Meanwhile, new types of poorhouses (jiaoyang yuan) were established as reformatories for convicts, and the centuries-old poorhouses, such as universal-relief halls ( $p u$ ji tang), were converted into "indoor institutions that required labour in exchange for relief" (Chen 2012: 31).

This shift from the centuries-old state relief system based on Confucian benevolence and Buddhist kindness to Western-style workhouses and poorhouses based on "compulsory labour in exchange for relief" demonstrates the influence of Western social ideas and institutions on China's social relief ideas and institutions.

\section{The Rise of the Social Question: Non-Marxist Versus Marxist Concepts, 1900-1920s}

In the early twentieth century, the terms "social problems" and "social policy" emerged in China shortly after the introduction of Western sociology into China, along with socialism and, later, Marxism. By the 1920s, Chinese mainstream intellectuals mainly consisted of returned students, first from Japan, then from Europe, and the USA. Among them were China's early sociologists, who were trained in the classical sociological tradition for which Auguste Comte (1798-1857), Herbert Spencer (1820-1903), and Emily Durkheim (1858-1917) advocated. Meanwhile, Marxism became very influential following the 1917 Russian Revolution, the 1919 May Fourth movement and the establishment of the CCP in 1921. Thus, the 1920s saw the emergence of both non-Marxist and Marxist concepts of social problems and social questions.

Sociology was first introduced into China in 1895 when Yan Fu described Spencer's sociological studies together with Darwin's theory of evolution in his article On the Origin of Strength (yuan qiang). In this article, Yan Fu describes how Spencer established sociology as a science of 
society, his basic sociological principles, subject-matter, and research methods (Ding 1988: 86-87). In 1903, Yan Fu translated Spencer's most influential book The Study of Sociology (1874), the first book with "sociology" in its title. Spencer was the single most influential sociologist in the late nineteenth century; he inherited the conceptions of society and sociology from Comte while adding his evolutionary framework to the new discipline. For Spencer, society was an organic whole, and sociology was "a holistic, naturalistic, and evolutionary science of society" (Breslau 2007: 40). Spencer's evolutionary sociological ideas had a profound impact on Chinese intellectuals and sociologists in the early twentieth century.

Marxism came to China at the turn of the twentieth century, however, in the name of socialism. In the beginning, socialism was often refuted as radical, inhuman, and unsuitable for China and, thus, had little influence in intellectual circles. It was not until after the 1919 May Fourth Movement, and even after the establishment of the CCP in 1921, that Marxism began to become increasingly influential, as a small group of Communist theorists disseminated Marxism, especially Leninism. These early Marxists, like Qu Qiubai and Shi Fuliang, taught at Shanghai University (1923-1927), the only higher institution that taught such courses because it was controlled by the nascent Communists. When teaching, they adopted Marxist books as their major textbooks, such as Bukharin's Historical Materialism (1921) and Lenin's Imperialism (1917) (Chiang 2001).

In the 1920s, China's mainstream intellectuals, some of whom became GMD party members, and Marxists began to debate China's "social problems". These contemporary writings included the term "social problems" in their titles, and not only discussed "social problems" in general but also analysed specific social problems regarding family, women, vagrancy, poverty, and labour. The debates focused on: what is society? What are social problems? What is or are China's most important social problem or problems? What are the causes of China's social problems? And what are solutions to China's social problems?

Almost all Republican non-Marxist intellectuals accepted the classical sociological idea of "society as a social organism" (Tsin 1997, 1999; Culp 2017). They also viewed "social problems" as a social disease threatening 
social order. But Republican intellectuals disagreed on the most important social problems in China and their solutions. That is, in the 1920s, sociologists and many other intellectuals agreed that poverty was the most pressing issue, while Marxists argued that the labour question was the most important, and Nationalist leader Sun Yat-sen focused on the land question as the most fundamental. Mainstream intellectuals, including Nationalist leaders, advocated for social policy while refuting social revolution and class struggle, for which only Marxists advocated.

One of the earliest scholarly books on social problems was written by Tao Menghe, a representative of China's early sociologists, professor, and chair of the Sociology Department of Beijing University in the 1920s. Tao published his 1924 book titled Social Problems (shehui wenti) as a textbook for senior high school students. Tao defined a "society" as "an organic collection of individuals" and "social problems" as "the diseases of a society" that hindered humans' collective lives (Tao 1924: 15). Tao criticised Marxist explanations for social problems as relying on a single factor (the economy) and discussed the natural, biological, demographic, psychological, economic and historical factors that cause "social problems". Tao then identified "poverty" as the fundamental and central social problem in China (ibid., 174-175). Tao applied his multi-factor explanation to rank the importance of these factors for contributing to poverty, natural and political were the most important, familial factors were very influential, and only after those factors were under control could economic and labour conditions be addressed, and they were not the only ones. As Tao put it, "if people had the ability to control nature, if political integrity could be achieved, and if new economic organisations could be developed, then economic and labour conditions might be the most important causes of poverty", he continued, "we should not think that they are the only causes for poverty" (ibid., 165). Tao discussed poor relief as temporary solutions and social reforms as fundamental solutions to poverty.

On the other hand, China's early socialists and communists, such as Li Dazhao, Chen Duxiu, Qu Qiubai, and Shi Fuliang argued for Marxist explanations of social problems, which Tao criticised. Shi Fuliang taught a course on Social Problems at Shanghai University. Based on his translated book Outlines of Social Problems (1929), we can discern the content 
of his course. As he made it clear, his book was a translation of the work of Japanese socialist intellectual Hitoshi Yamakawa (1880-1958), a leader in establishing the Japanese Communist Party in 1922. The book gives a Marxist analysis of the social question, which he regarded as the labour question, a product of capitalism. In the preface, Shi put it directly, "The labour question, which is at the centre of all social problems, is the product of capitalist contradictions. The solution to capitalist contradictions is socialism" (Shi 1929: 2). In this book and his 1930 book on social problems, however, Shi did not particularly discuss China's social problems (Shi 1930).

However, GMD labour leaders and sociologists discussed China's labour question using non-Marxist concepts. Ma Chaojun (1885-1977), who studied political economy at Meiji University in Japan and served as the head of the Labour Bureau of the Nationalist state in 1927, pointed out in his 1926 book China's Labour Question that the labour question was the most important social question in the world, but it was not the time for Chinese labourers to fight capitalists yet, as there were not any capitalists in China due to China's inadequate production. Ma criticised those calling for "labourers to rise up to fight capitalists" as being "ignorant of the time and circumstance" (1926: 3). His solution to China's labour question was to provide labour protection measures rather than class struggles as promoted by the communists.

Chen Da, a most accomplished sociologist on China's labour question, expressed similar views in his 1929 China's Labour Question; as he put it, "in our country, this (labour) question is simpler than that of the West, but it will become more complicated with the development of China's industry. So it is necessary to study China's labour question without any delay" (Chen 1929: 2). Chen also proposed that developing welfare institutions, such as compulsory insurance, was the fundamental solution to the labour question.

Most of the sociologists and early Marxists, who were still at the stage of absorbing Western ideas, which were industry and urban oriented, did not pay enough attention to the land question as well as related peasant 
problems until the 1930s. ${ }^{2}$ However, Sun Yat-sen, the founding father of the GMD and the Republic of China, insisted that the land question should be China's biggest social question as demonstrated in his lectures on people's livelihood in 1924. In these lectures, Sun refuted Marxism and criticised Marxist class struggle as "inverting causes and effects" and argued that China's social question should be solved by "equalising land rights" and "regulating capital", which meant preventing large landlords from controlling key industries. Sun continued to argue that, because of China's poverty and insufficient industrial production, China should develop its national capital and revive industrial production (Sun 1924, Lectures I and II).

The ruling Beijing government, although unstable and short lived, did respond to these social problems. In 1915, it inherited and continued its support for the Qing Dynasty's workhouses by issuing Regulations on Vagrant Workhouses (youmin xiyisuo) "to nurture young homeless people and reform juvenile delinquents (aged 8-16 years) so that they have the general knowledge and basic skills to make a living" (Yue 2006: 227-228). For the labour question, the Beijing government, under the pressures of the CCP-led labour movement, the GMD's Southern Regime, and the ILO, issued its Provisional Factory Regulations in 1923 (revised in 1927) and the Factory Inspections Regulations in 1927. The two factory regulations and the factory inspections regulations, however, were not implemented because the GMD government soon replaced the Beijing government ( $\mathrm{Hu} 2015)$.

\section{The GMD State's Social Policy: State-building, Productivism, and Collectivism, 1927-1937}

Upon ascending to power, the GMD state started its state-building process, which claimed to follow Sun Yat-sen's legacy, notably his three peoples' principles and his three-stage process of revolution (from military rule through political tutelage to constitutional government). In 1929,

\footnotetext{
${ }^{2}$ However, Mao Zedong, the would-be founder of the People's Republic, was a notable exception and carried out several surveys on peasant issues in the 1920s.
} 
the GMD state claimed to enter the political tutelage stage, in which the GMD had the highest power in the political system and would guide state affairs. By the early 1930s, a five-sector government, or a five-yuan system, was established, following the American model (Myers 2000; Strauss 2000). By 1935, Jiang Jieshi (known in Western countries as Chiang Kai-shek) became the indisputable leader after winning over local warlords, driving the CCP out of its Jiangxi base and defeating his political competitors.

Under the GMD's one-party rule, the dynamic and tolerant political environment of the 1910s and 1920s changed dramatically. The GMD state was explicitly against Marxist class struggle as well as the individualism of capitalist society. It promoted an "inclusivist and co-optive strategy" to incorporate all those who could be co-opted because of the GMD's belief in "the organic unity of the Chinese people" and its fear of open division (Strauss 2000: 90). This strategy was the result of incorporating Confucianism into the party-state's ideology and learning from the West, including fascism. Fascism was only viewed as a way of restoring China: the GMD state was not fascist in nature but an authoritarian and military dictatorship (Wakeman 2000; Clinton 2017; Tsui 2019).

In the field of social policy, the GMD state immediately responded to the social problems widely discussed in the 1920s. To solve the poverty problem, it issued a series of regulations affecting poor relief organisations and private charities, with the dual purposes of providing welfare and social control. By 1935, these regulations consolidated existing poorhouses and workhouses within an administrative jurisdiction into a single relief home and brought private charities under the state's control (Cai 2003: 254-261). In response to the labour question, the GMD state drafted the famous Labour Code Draft in 1929, which did not become law but served as the model for a series of labour protection laws issued in the early 1930s and a labour insurance bill that was not issued because of the breakout of the Second Sino-Japanese war. The GMD state's social policy was outlined in its 1931 Provisional Constitution in chapter four, which covered the "national livelihood" (guomin shengji). While the relief homes functioned to some degree-although not always fulfilling their stated purposes - the labour laws basically were never put into practice. This was mainly due to the fact that these laws copied the contents of 
Western laws, which surpassed the financial and administrative abilities of the Chinese state. Rhetorically, Sun Yat-sen's three peoples' principles, especially people's livelihood, guided the GMD state's policy for poor relief and labour protection. In reality, the immediate purpose of these policies was to root out communist influence (Ma 1927).

Productivist approaches adopted in 1927 greatly influenced the GMD state's social policy, which had its roots in Sun Yat-sen's people's livelihood principle. In 1924, Sun Yat-sen ultimately "identified an increase in national production as the central solution to the social problem" (Zanasi 2006: 70). The GMD state pursued Sun's productivism to guarantee people's livelihood, which, in turn, reinforced the state's belief in "compulsory labour in exchange for relief". Due to the GMD state's productivism, officials and sociologists alike frequently criticised China's traditional poor relief as passive and as producing paupers. In his 1935 book on China's poverty, Ke Xiangfeng identified that the result of China's traditional relief policy was "a society full of beggars, even professional beggars, and dependent poor" (Ke 1935: 325-326). As a correction to China's traditional relief policy, the GMD state claimed that its poor relief provided active relief through compulsory labour to help recipients become independent and turn them from consumers into producers.

Collectivist notions of society and social problems also influenced the GMD state's social policy. Following the introduction of Spencer's works, Durkheim's The Rules of Sociological Method (1895) was translated into Chinese in 1924 and methodologically defined sociology as an independent and positivist social science. In 1935, in the midst of the GMD state's revitalisation of Confucianism, Durkheim's The Division of Labour in Society (1893) was translated into Chinese. This book presented Durkheim's main concern for how to maintain social order through "mechanical solidarity" in "primitive societies" and through "organic solidarity" in advanced industrial societies, as well as his concern for the transition from primitive to industrial societies, which, he argued, might lead to major crises and anomie that was pathological to modern society.

Durkheim's two books were well received. According to Sun Benwen, arguably the most important official sociologist in the Republican era, Durkheim's two books were the most important sources of China's 
"synthesis school" of sociology, which was very influential in this time period (Sun 1948 [2011]: 270). Sun identified himself with this school in 1948, whereas before he had been well known for his emphasis on cultural factors (ibid., 276-279). It is not difficult to understand why China's official sociologists received Durkheim's works so well. Durkheim's concerns with the transition from a traditional to a modern society agreed with China's situation, as the GMD state engaged in modernising China. In addition, Durkheim's notion of "society as a social organism", which emphasised that society had a common purpose that transcended those of individuals, and it would impose that common purpose on its individual members, fit in squarely with China's Confucianism, which was being revived under GMD rule. Thus, the GMD state could take advantage of this notion to justify the party's authoritative rule over society.

Sociologist Zhu Yisong, one of the leading scholars of the synthesis school, wrote about introductory sociology as well as social problems and social policy. His 1933 Social Policy was one of a very few books that discussed China's social policy in the 1930s; although there were several books published with the term "social policy" in their titles, they were either Chinese translations of foreign works or merely introductions of foreign social policies. The notion of a social organism inspired Zhu's book, and he argued that the purpose of social policy was to increase order, peace, and harmony. Zhu's arguments were in agreement with the GMD state's official ideology.

In Social Policy, Zhu treated society as a system which had both harmonising and conflicting interests and defined social problems as "problems that have threatened the order, peace, and happiness of society" (1933: 4). He argued for adopting a social policy that could increase the interests of a society or state (labelled as harmonising interests) and decrease the interests of groups or individuals (labelled as conflicting interests). As Zhu put it, social policy's purpose is "to coordinate all sorts of interests so that groups and individuals can realise their interests under a single social system" (ibid., 6). He continued that, "a society thus achieved is a democratic society", and "such a society will be full of happiness, people will be friendly with one another, and such a society will become a closely connected organism, in which there will be no room for a philosophy of hatred" (ibid.). Finally, Zhu argued that in such a society 
Marxism would naturally lose its attraction for workers, peasants and young people: as he put it, "when the soil becomes unsuitable, Marxists will not harvest anything even if they disseminate the seeds" (ibid.).

While the GMD determined to uproot the CCP's influence, the CCP survived in rural areas. However, the communist-controlled Shanghai University closed in 1927, Qu Qiubai, a CCP leader, was executed, and Shi Fuliang was expelled and his translations of Marxism were banned. Nonetheless, the CCP established 15 bases in rural areas from 1928 to 1934. The Soviet Union strongly influenced the policies of the CCP's Central Committee by appointing its leaders. In February 1930, the Far Eastern Bureau of the Comintern helped the CCP Central Committee draft five laws on land, labour, economic policy, the red army, and organisation of the Soviets, respectively, which were the basis for the Outline of the Constitution, Land Law, Labour Code, and Resolution on Economic Policies all issued in 1931. These laws attempted to establish a political regime modelled on the Soviet socialist system (Yu 1995: 45-46).

The Labour Code was applied to all workers in all sorts of enterprises, imitating the Soviet Labour Code of the 1920s in all aspects. It stipulated an eight-hour workday, a series of paid public holidays that totalled 175 days per year, a high level of wages and welfare, and a set of comprehensive social insurance benefits (ibid., 90-99). However, implementation of the Labour Code was a failure. By spring 1933, the Labour Code caused the shutdown of many small enterprises and, thus, unemployment of workers, due to the unrealistic benefits mentioned earlier (Zhang and Sun 2011). As a result, half a year later, the CCP issued a revised Labour Code on 15 October 1933, which made it more flexible in terms of working hours and other labour conditions to suit local situations (Yu 1995: 338-356). However, the new Labour Code could not be fully applied because the CCP was driven out of its bases and began the Long March to Northwest China on 16 October 1934. 


\section{Wartime Social Policy: Universal Social Security and China's "Special Situation" (1937-1945)}

The outbreak of war with Japan did not change the features of the GMD state's social policy, which continued to be part of the nation-building process, embodied collectivist notions of social problems and attempted to promote production. On the other hand, however, the Atlantic powers introduced the idea of universal social security, which greatly attracted Chinese elites in social policymaking, although they continued to emphasise China's special situation.

The war made the refugee issue an unprecedented national crisis, which led to the establishment of the National Relief Commission (NRC) in 1938, an emergency organisation to deal with the refugee crisis. Meanwhile, the war provoked the GMD state to tighten its monitoring of mass mobilisation, and the GMD party consequently established the Ministry of Social Affairs in 1939.

However, in 1940, with the war at a stalemate, the Social Affairs Ministry was transferred to the Executive Yuan, which served as the state council and thus the highest administrative agency. The ministry not only retained its former responsibilities but also took over other social duties from the Interior Ministry, the Industries Ministry, the Economic Ministry, and the NRC. Accordingly, the ministry was made up of three subordinate departments for social welfare, social movements, and cooperative affairs, respectively. The social welfare department included six divisions and one bureau, each of which was, respectively, in charge of social insurance, labour welfare, social services, job centres, social relief, children's welfare, and factory inspections (Qin 1983b, vol. 97: 14-28).

The 1940s were a decade of "welfare internationalism" (Kaufmann 2012, chapter 4, 94-130). The term "social security" began to appear in international documents in the early 1940s. In August 1941, the Atlantic Charter referred to "the fullest collaboration between all nations in the economic field with the object of securing for all improved labour standards, economic advancement and social security". In 1942, the ILO, at its Montreal office, published Approaches to Social Security: An International Survey, which promoted the idea of coordinating and integrating existing 
social insurance and means-tested social assistance programmes into a single national scheme, as exemplified by the New Zealand system (ILO 1942). In November 1942, Britain published the Beveridge Report, titled Social Insurance and Allied Services, which embodied similar ideas as those of the ILO 1942 Survey. The Beveridge Report proposed a thorough plan for the government to address the five giants identified by the report: want, disease, idleness, ignorance and squalor. What the report proposed was a single national flat-rate social insurance system, which was universal in its population coverage and comprehensive in its covered social risks in order to provide a national minimum safety net via flat-rate benefits and contributions. More importantly, the Beveridge Report committed to three larger objectives, which were full employment, family allowances, and a general revenue-financed National Health Service system free for the entire population.

If the ILO's 1942 survey did not draw immediate attention, the Beveridge Report had an immediate impact on circulating the idea of a universal social security scheme and the post-war ideals advocated for in both the ILO survey and the Beveridge Report. The Beveridge Report became a milestone in the history of the development of the post-war welfare state. As Rodgers commented, "of all the welfare state programs and platforms that were to follow, none was to match its influence or the electricity of its reception" (1998: 489). As a result, the USA passed the Wagner-Murray-Dingell Bill in 1943 and Canada published its Marsh Plan in 1943. In 1944, India, supported by two ILO experts, considered issuing an Indian Beveridge Plan based on the Adarkar draft of a health insurance programme (Kumar 2003). The ILO further reinforced the ideas embodied in its 1942 survey and the 1942 Beveridge Report at its 1944 Philadelphia Conference, which recognised the ILO's obligation to advance global programmes that would achieve full employment, a basic income, and comprehensive medical care. In terms of social security, the Conference Declaration called for extending social security measures to provide not only a basic income but also a comprehensive medical care to all who were in need (Johnston 1970). China was not exempt from this global trend of emerging universal social security policies, especially under the leadership of the newly consolidated Ministry of Social Affairs 
staffed with Euro-American-trained sociologists and other social scientists (Hu and Manning 2010; Hu 2015; Ma 2012, 2014).

The Ministry of Social Affairs began to extensively recruit China's sociologists. Gu Zhenggang, the Social Affairs Minister during the ministry's existence (1939-1949), ${ }^{3}$ studied at Berlin University from 1922 to 1925 and returned to China in 1926 as a GMD party member. In 1931, Gu became a Deputy Minister for the Interior Ministry, then the Social Affairs Minister in 1939. Under his leadership, the Social Affairs Ministry appointed sociologists Xie Zhengfu and Zhang Hongjun as the head of the Social Welfare Department from 1942 to 1944 and from 1944 to 1949 , respectively.

Furthermore, the ministry invited Chinese sociologists to participate in every step of the ministry's work on social policy formation from the initial policy design through drafting legislation to assessing policy implementation. For instance, many sociologists attended a series of important conferences the ministry held from January 1941 to the end of 1942 (Qin 1983b, vol. 97). In 1942, based on the ministry's suggestions, sociologists from universities in the Chengdu region established a research committee on social relief, and the ministry's Research Office began to edit a book series on social administration written by Chinese sociologists (Ke 1943: 1). By 1944, universities began to add sociology departments and opened courses on social administration and social affairs (Yan 2010: 261-262). The ministry also recruited university graduates and dispatched outstanding ones to study social policy in the USA and Europe.

As a result of the ministry's intensive efforts, the Social Relief Law was promulgated in 1943. Compared with its forerunner-the 1928 Regulations on Local Relief Homes-this law significantly enlarged its target groups and improved the benefit levels, a result of learning from worldwide trends. As the ministry put it in its explanation of the social welfare bill, "according to the implications of the Grand Unity (Da Tong) in the Books of Rites on relief principles and in reference to various countries' relief administration trends, we have drafted this social relief bill"

\footnotetext{
${ }^{3}$ In 1949, the Social Affairs Ministry was abolished and its major responsibilities were incorporated into the Interior Ministry under its Social Affairs Department, and Gu Zhenggang became the Minister of the Interior Ministry in 1950.
} 
(Yue 2006: 236). According to the ministry, the bill adopted four major ideas embodied in worldwide trends. First, it assumed the idea of state responsibility and abandoned former ideas of benevolence and kindness in providing social relief. This means that it is the state's responsibility rather than the state's mercy and grace to provide social relief. Second, accordingly, relief methods should transition from passive, post-event material assistance only to preventive and positive relief to help people become independent, useful instead of useless, and producers instead of consumers. Third, coverage should be extended from "the poor, old and weak, and disabled and sick" (pinqiong laoruo canji) to the entire population, including pregnant women, children, the physically disabled, and labourers, as well as citizens in such situations as renting a home, contributing to economic cooperatives, and providing for family consumption. Benefits should cover all types of contingencies. As the ministry put it, "all countries around the world have provided their peoples with all sorts of benefits from birth to death". Fourth, with the expansion of coverage and circumstances, the state should take responsibility and also greatly encourage people and organisations to operate private relief organisations (ibid., 236-238).

The passage of this social relief law also reflected changes in attitudes towards poverty. As early as the turn of the century, eradicating poverty was linked to China's national survival. By the 1920s, Chinese elites largely emphasised the personal flaws of the poor and blamed them for their poverty, and criminalised vagrants and other poor. In the 1930s, sociologists, like Ke Xiangfeng, differentiated "pauperism" from "poverty": pauperism was defined as "dependency on others who were not naturally or legally responsible" for them (1935: 10). This implies that poverty rather than pauperism should be socially supported. It was in the 1940s during the war that intellectuals began to emphasise that "poverty is not a crime", and laziness was not the source of poverty but, instead, social factors, such as the war, caused many diligent and frugal people to experience poverty (Zhou 1944).

From its inception, the ministry recognised the novelty and importance of social insurance in solving social problems that industrialisation created and maintaining social order. It planned to set up a Social Insurance Bureau in the near future. It viewed drafting social insurance 
bills as one of its major tasks: for that purpose, it collected and translated a series of social insurance laws from Euro-American countries and the Soviet Union. By 1943, the ministry had already drafted a series of social insurance bills, and a Chinese translation of the Beveridge Report reached the Ministry in 1943, leading to wide-ranging discussions of its major ideas by the ministry's experts and the desire to draft China's own Beveridge plan in 1944 (Ma 2012: 337-344). Although no social insurance laws were enacted during the war, the ministry chose the district of Ziliujin in Northern Sichuan to experiment with social insurance funds for salt miners. In 1943, it had established about ten insurance societies in ten counties, covering around 50,000 workers altogether.

Overall, although "world trends" played an important role in the GMD state's wartime social policy formation, Chinese intellectuals and officials emphasised China's inherent social ideas and China's own situation, as demonstrated by a 1943 GMD Propaganda Department document on wartime social administration. This document first stated that China's inherent ideal society was harmonised, and then it discussed major features of China's social administration as compared to those of Euro-American countries. This shows the GMD state's continued rhetoric reliance on Confucianism while learning from the West.

According to this document, we can summarise the major features of China's social administration as follows. First of all, as the purpose of China's state-building was to realise the three peoples' principles, the party-state needed to train the masses to achieve national independence. Second, while Western countries were industrialised and their living standards were relatively high, China was still primarily agricultural and all socio-economic levels of society suffered from low living standards, especially when China was at war. Therefore, although Western countries' social administration programmes focused on redistribution, China's social administration should aim to improve industrial production. Third, while Western countries had class conflict caused by capital, China had no classes at all. As a result, while Western countries' social policies targeted workers to reduce class conflict, China's social policies needed to target the entire population to prevent the emergence of classes (Qin 1983a, vol. 96: 15-49). 
In 1944, in his article "Several Principles of Social Administration from the Last Three Years", the Social Affairs Minister Gu Zhenggang analysed the issue of what kind of social policies China should adopt. In this article, $\mathrm{Gu}$ mentioned that China's social administration's biggest task was to solve China's social problems and complete its social reconstruction. Whereas there were three kinds of global social policies-capitalist, socialist, and fascist-he recommended that China should adopt the three peoples' social policy because of China's state ideology, social needs, and social problems. As Gu put it, "we should know that state ideology and social needs are the two conditions that determine the types of social policies of any country. The three peoples' principles are our country's supreme ideology and principles, and our country's social problems have their own nature. Therefore, our social policy must be based on the three peoples' principles" (Qin 1983c, vol. 99: 1-3).

Upon the outbreak of the war, the GMD and CCP formed a second united front, and the CCP abandoned "its policies of armed revolt, sovietisation, and forcible confiscation of landlords' land" (Van Slyke 1967: 92-93). With the war's stalemate in late 1939 and 1940, the united front became fragile due to both military and ideological conflicts. In response, in January 1940, Mao Zedong published his essay "On New Democracy", arguing for the establishment of a new democratic republic that would be a proletarian-led, multi-class coalition regime in transition to a socialist regime (Mao 1940). In other words, the essay emphasised class coordination between national capitalists and the working class as well as a transition to a socialist regime in the future.

Accordingly, in late 1940 and 1941, the CCP promoted a wartime labour policy that abandoned its previous radical labour policy (Central Committee 1985, vol. 3: 42). The Labour Policy Outline provided concrete measures for major aspects of labour policy. The Labour Policy Outline pointed out that "social insurance should be set up as contingencies for sickness and death"; however, "if there are difficulties in setting up social insurance, regulations on benefits for workers' injuries, accidents, and deaths should be provided" (ibid., 52-54).

During the rectification campaign of 1942 and 1943, the CCP further criticised the radical labour movement as subjective, which "blindly applied the set of measures suitable in industrial urban areas to the 
wartime base areas", and was described as "rural, economically backward, repeatedly attacked by enemies, and characteristic of the new democratic economy and politics" (Tang et al. 2002: 537-539). Thus, production, rather than improving workers' livelihoods, was stressed, especially after Mao's 1943 call "to organise up", which led to another round of largescale production campaigns (Mao 1991: 933).

As a result of implementing the wartime labour policy that emphasised class coordination and increased production, social insurance disappeared in all labour protections and collective contract regulations issued by administrators in major bases from 1941 to 1944 (ibid., 75-119). In contrast, we recall that social insurance was part of the 1930s Labour Code, and, as late as 1940 , public enterprises in a major base area offered labour insurance funds to provide benefits to workers' families in the event of sickness, death, or injury (Xinhua Daily, 1 May 1941, in ibid., 149). Yet, wartime regulations provided labour compensation rather than social insurance benefits.

\section{Post-war Development: Establishing Social Security Institutions, 1945-1978}

In May 1945, at its Sixth National Congress, the GMD adopted its famous four principal social policies, including the National Health Programme, Labour Programme, Agrarian Programme and Preliminary Facilities for a Post-war Social Security Programme (Chinese Ministry of Information 1947). The post-war social security programme was brand new, and the 1942 British Beveridge Report and the ILO's post-war reconstruction plan greatly influenced it. It used the term "social security" in its title and pointed out that, "the main tasks of a postwar social security programme shall be vocational guidance, social insurance, and social relief"; and "social insurance" referred to a comprehensive social insurance programme, its financial sources, and principles for determining benefits (ibid., 52). In 1946, the GMD state approved "Implementing Measures to Establish Preliminary Facilities for a Postwar Social Security Programme", which provided a strategy and specific agenda for setting up 
social insurance programmes (Chen 1984: 368). Meanwhile, the 1947 Constitution provided "social security".

In 1946, the GMD government was able to set up a Preparation Department to establish the Central Social Insurance Bureau under the Ministry of Social Affairs. This Preparation Department drafted Principles for Social Insurance Laws (shehui baoxianfa yuanze), which was passed by the National government's state conference in 1947 and became the first social insurance law in modern China. The explanation of the 1947 Principles made clear reference to the British National Insurance Act of 1946, and the ILO's publications, such as the ILO's 1942 Approaches to Social Security, and many other contemporaneous foreign laws and materials (Nanjing Archives 1947). In 1948, China not only participated in the drafting of the United Nations' Universal Declaration of Human Rights but also ratified the declaration, which included social security as a major human right. The GMD took over the workhouses and poorhouses in areas Japan previously occupied. With hyperinflation, the collapse of the economy, and the deterioration of the refugee situation, poverty-related problems became even more challenging, although the GMD state continued to stress positive relief and labour productivity.

On the eve of victory in the Second Sino-Japanese War, the CCP claimed to continue its wartime new democratic labour policy and called for a social insurance programme. As Mao Zedong contended in his 1945 report "On Coalition Government", the government would adopt social insurance, eight- to ten-hour workdays and unemployment relief to protect workers' interests (Mao 1945). As a result, from 1945 to 1948, various bases adopted labour protection regulations that included a section on "labour insurance" or "social insurance" (Zhou et al. 2002: 326-347). As the CCP took over more and more cities from the GMD, they called for a meeting of trade unions from all liberalised areas in 1948, which turned into the Sixth National Labour Conference. Labour insurance for public enterprises became a major issue at the conference because the number of state enterprises had increased. Thus, the Resolution of the Conference states that "places with large concentrations of industrial workers can initiate labour insurance programmes" (AllChina Trade Union 1957: 373). Shortly after the Sixth Labour Conference concluded, in December 1948, the Northeast Region adopted a labour 
insurance programme, which was based on the Soviet model of social insurance.

In 1949, the People's Republic was officially established in October, and, upon its defeat, the GMD central government retreated to Taiwan in December. Shortly thereafter, in 1950, Taiwan adopted a labour insurance programme at the provincial level, while China adopted its labour insurance model at the national level in 1951. Both labour insurance systems were continuations of the GMD and CCP's pre-1949 efforts to provide social insurance ( $\mathrm{Hu} 2015,2016)$. The fate of each system, however, contrasted greatly in the following decades, until the early 1980 s when China entered a new era. By 1952, Taiwan's labour insurance programme had rapidly extended to all enterprises with more than ten workers, while in the 1950s separate labour insurance schemes were established for the self-employed, fishermen, and sugar employees. In 1958, all these existing systems were incorporated into a single labour insurance system (Hu 2015). In contrast, China's labour insurance scheme only applied to enterprises with 100 workers or more, and the system's operation deteriorated during the Great Leap (1958-1960) and broke down completely during the Cultural Revolution (1966-1976).

In both China and Taiwan, government employees and military servicemen received privileged social benefits either in the form of social insurance as in Taiwan or from the state's budget as in China. By the 1980s, only farmers, housewives, and other unemployed populations were excluded from the existing social insurance system in Taiwan, but in China, a much larger population remained without coverage as "state paternalism" was "practiced on the principle of exclusivity" (Lee 2019: 59). In Taiwan, the 1943 social relief law was in effect until 1980, and, in China, the government provided both emergency and social relief to urban residents.

Furthermore, China implemented a separate social security system for peasants due to the urban-rural divide. This divide materialised as a result of the household registration system that the government developed in the 1950s, which classified the population into rural and urban residents and made it extremely hard for rural residents (peasants) to become urban residents. In the countryside, the state inherited the emergency relief system and set up a system for the wubaohu (households similar to the 
historical guangua gudu fei) in which local rural collectives rather than the government provided them with the basics like food, clothing, and housing. The state provided free public education and organised rural health cooperatives for all rural residents through the local People's Communes (for China's Commune welfare programme, see Dillon 2015). Both systems were globally recognised and highly praised. This rural system has undergone great changes since 1978, when China officially entered the reform and opening-era (Shi, Chap. 3 of this book).

\section{Conclusion: Ideas and Reforms}

This chapter analysed the rise of social security ideas and policies in China in the first half of the twentieth century using Leisering's "onion skin model" of social policy ideas (see the summary in Table 2.1). It first discussed China's imperial state relief policies and demonstrated the influence of Western missionaries and Western poor relief on China's relief system from the late nineteenth century to the first decade of the twentieth century. It then analysed the rise of social problems and the social question in China in the 1920s, and the accompanying debates between China's mainstream non-Marxist intellectuals and early Marxists at a time when the political environment remained tolerant before the GMD came to power and suppressed Marxism and liberalism. Parts three to five examined the GMD state's social security policies during its reign from 1928 to 1949 and argued that its social policy was regarded as part of its state-building processes and it adopted collectivistic notions of social problems and social policy that emphasised production rather than redistribution and individual rights. In particular, part four explored the wartime social policy, including the impact of universal social security ideas on the GMD state's social policy. Parts three to five also introduced the CCP's social security policies in the areas that it controlled.

Several ideational points are worth highlighting. First, this chapter revealed that there was an early rise in social security ideas and institutions in China in the first decades of the twentieth century, although these ideas often did not become bills, bills often did not become legislation, and related laws were often not implemented due to China's weak 


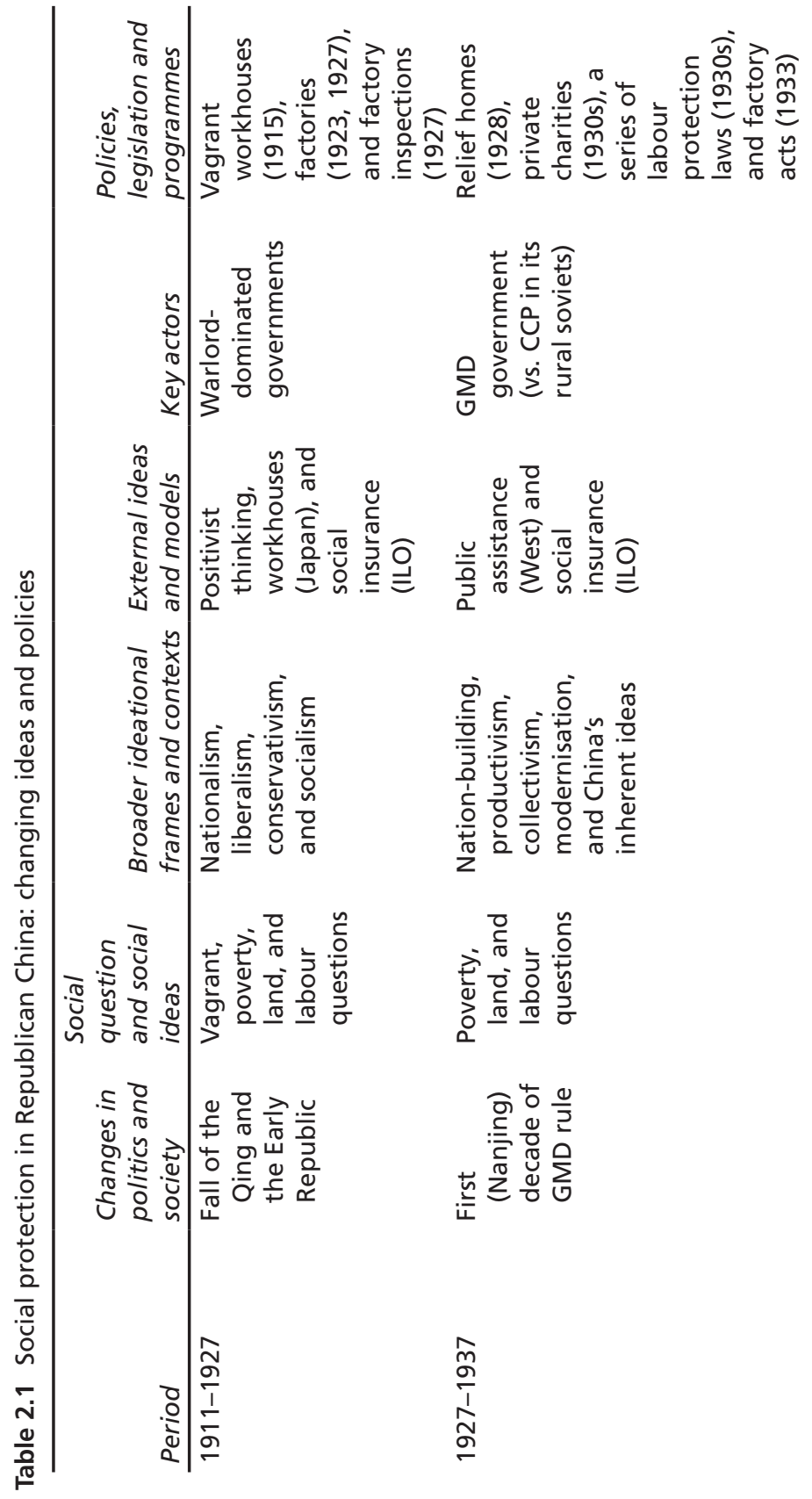




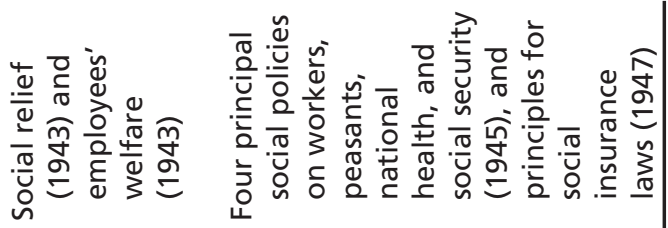

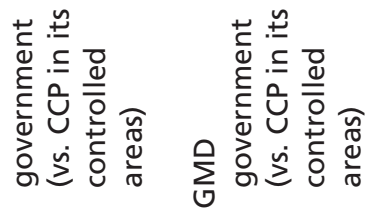

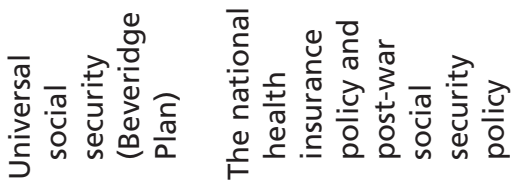

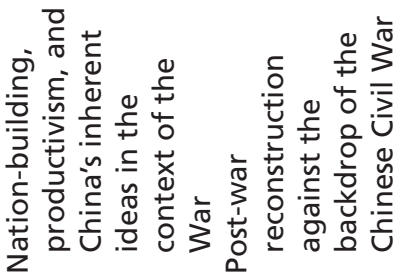

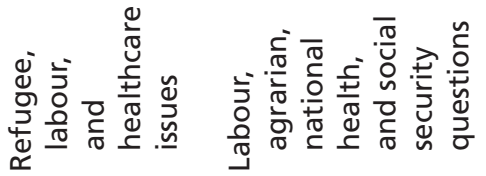

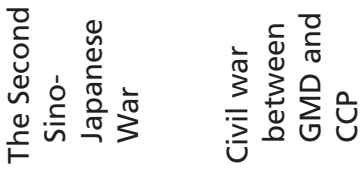

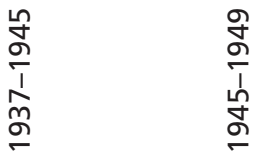


central state during this turbulent time. The early 1940s, however, began to see intensified social policy development in China, partially due to the great impact of the Allied powers' universal social security ideas on China. The result was the issuance of a series of social security laws and decrees, including the Social Relief Law in 1943, the Employee's Welfare Law in 1943, and the Principles of Social Insurance Laws in 1947. In addition, the GMD party issued the Four Principal Social Policies in 1945, which included the first policy with the term "social security" in its title. This, in turn, paved the way for "social security" to be written into the 1947 Constitution. Unlike most of the laws in previous decades, the two laws on social relief and employees' welfare were not only implemented but also had a significant impact (together with the 1947 Principles) on Taiwan's social security throughout the post-war era.

Second, the above-mentioned two laws from 1943 also had an impact on Communist China's social security policies in the sense that China carried on the enduring tradition of state emergency relief and continued some social relief and employee's welfare practices in the 1950s. It thus partially agreed with the recent literature, arguing there were ideological and practice continuities across the 1949 divide between the GMD and CCP regimes. However, this chapter insisted that the GMD state's social security policy was the direct source of Taiwan's social security programme in the post-war era, whereas Communist China's social security model originated in the areas it controlled before 1949 and emulated the Soviet models as shown by pertinent discussions throughout this chapter.

Third, in Republican China, almost all non-Marxists, who remained the mainstream intellectuals, accepted the organic concept of society promulgated in the classic sociological tradition of Comte, Spencer and Durkheim, which viewed "social problems" as social diseases that threaten the social order. The organic concepts of society led to a concern for stability and harmony in society, and this concern was reinforced under the GMD rule in the 1930s when Confucianism was incorporated into the party-state's ideology. By abandoning Marxist notions of class struggle and radical revolution, as well as suppressing liberal notions of individual rights, the GMD state adopted collectivist notions of social policy, which emphasised economic growth and increasing production. 
Fourth, although external ideas played an important role in China's social security policy as discussed earlier, Chinese elites emphasised China's special situation when debating and designing China's social policy. The GMD state recruited many Western-trained sociologists to its social administration as advisors and officials, especially after the Ministry of Social Affairs was established in the 1940s. While these intellectuals and officials paid close attention to global trends, they consistently argued that China's social problems had their own causes and forms, which were different from those of the West, and China had its own state ideology, which was different from foreign ones. Thus, they continued, China should not adopt any existing foreign social policies (neither Soviet, capitalist, nor fascist), but its own social policy based on China's special situation, which was officially labelled as the three peoples' social policy.

\section{References}

All-China Trade Union (eds.) (1957) Selected materials from all conferences of the All-China Trade Union. Beijing: Workers' Publisher.

Béland, Daniel, and Klaus Petersen (eds.) (2014) Analysing social policy concepts and language: Comparative and transnational perspectives. Bristol, UK: Bristol University Press and Policy Press.

Breman, Jan, Kevan Harris, Ching Kwan Lee, and Marcel van der Linden (eds.) (2019) The social question in the twenty-first century: A global view. Oakland, California: University of California Press.

Breslau, Daniel (2007) The American Spencerians: Theorizing a new science. In Sociology in America: A history, ed. Craig Calhoun, Chicago: University of Chicago Press, 39-62.

Cai, Qinyu (2003) State, society, and the vulnerable: Social relief in the Republic of China, 1927-1949. Tianjin: Tianjin People’s Publisher.

Central Committee of the CCP (eds.) (1985) Selected documents on the Labour Movement, vol. 3. Beijing: Central Committee of the CCP.

Chen, $\mathrm{Da}$ (1929) China's Labour Question. Shanghai: Commercial Press.

Chen, Guojun (1984) Social policy and social legislation. Taibei: Three Peoples' Press.

Chen, Janet (2012) Guilty of indigence: The urban poor in China, 1900-1953. Princeton: Princeton University Press. 
Chiang, Yung-chen (2001) Social engineering and the social sciences in China, 1919-1949. Cambridge: Cambridge University Press.

Chinese Ministry of Information (eds.) (1947) China handbook, 1937-1945: A comprehensive survey of major developments in China in eight years of war. Revised and enlarged edition. New York: Macmillan.

Clinton, Maggie (2017) Revolutionary nativism: Fascism and culture in China, 1925-1937. Durham: Duke University Press.

Culp, Robert (2017) Articulating citizenship: Civic education and student politics in Southeastern China, 1912-1940. Cambridge, MA: Harvard University Press. Dillon, Nara (2015) Radical inequalities. Chinas revolutionary welfare state in comparative Perspective. Cambridge, MA and London: Harvard University Press.

Ding, Yi (1988) On the original introduction of Western sociology into China. Sociological Studies 6: 86-87.

Eastman, Lloyd E. (1984) Seeds of destruction: Nationalist China in war and revolution, 1937-1949. Stanford: Stanford University Press.

Fung, Edmund S. K. (2010) The intellectual foundations of Chinese modernity: Cultural and political thought in the Republican era. Cambridge, UK: Cambridge University Press.

$\mathrm{Hu}$, Aiqun (2012) The global spread of neoliberalism and China's pension reform since 1978. Journal of World History 23,3: 609-638.

$\mathrm{Hu}$, Aiqun (2015) China's social insurance in the twentieth century: A global historical perspective. Leiden: The Brill Academic Publisher.

$\mathrm{Hu}$, Aiqun (2016) Social insurance ideas in the People's Republic of China: A transnational and historical analysis. Transnational Social Review 6,3:297-312.

$\mathrm{Hu}$, Aiqun and Patrick Manning (2010) The global social insurance movement since the 1880s. Journal of Global History 5,1: 125-148.

Huang, Hongshan (2011) Research on charity in Modern China: Centred on Jiangnan in the Late Qing Dynasty. Tianjin: Tianjin Guoji Chubanshe.

International Labour Organization (1942) Approaches to social security: An international survey. Montreal: International Labour Office.

Johnston, G. A. (1970) The International Labour Organization: Its work for social and economic progress. London: Europa.

Kaufmann, Franz-Xaver (2012) European foundations of the welfare state. Trans. John Veit-Wilson. New York: Berghahn Books.

Kaufmann, Franz-Xaver (2013) Thinking about social policy: The German tradition. Trans. Thomas Dunlap. Berlin, Germany: Springer.

Ke, Xiangfeng (1935) China's poverty issue. Shanghai: Zhongzheng Shuju. 
Ke, Xiangfeng (1943) Social relief. Shanghai: Zhongzheng Shuju.

Kettunen, Pauli and Klaus Petersen (eds.) (2011) Beyond welfare state models: Transnational historical perspectives on social policy. Cheltenham, UK: Edward Elgar.

Kumar, S. Vijaya (2003) Economic security for the elderly in India: An overview. Journal of Aging \& Social Policy 15: 45-65.

Lee, Ching Kwan (2019) The social question as the struggle over precarity: The case of China. In The social question in the twenty-first century: A global view, ed. Jan Breman, Kevan Harris, Ching Kwan Lee, and Marcel van der Linden, Oakland, California: University of California Press, 58-76.

Leisering, Lutz (2019) The global rise of social cash transfers: How states and international organizations constructed a new instrument for combating poverty. Oxford: Oxford University Press.

Leung, Joe C. B. and Richard C. Nann (1995) Authority and benevolence: Social welfare in China. Hong Kong: The Chinese University Press.

Liang, Qizi (1997) Shishan yu jiaohua: Ming-qing de cishan zuzhi (Charity and moral indoctrination: Philanthropic organisations of the Ming and Qing Dynasties). Taibei, Taiwan: Lian Jing Publisher.

Ma, Chaojun (1926) China's Labour Question. Shanghai: People's Intelligence Publisher.

Ma, Chaojun (1927) Introduction. Labour Monthly 1.

Ma, Tehyun (2012) A Chinese Beveridge plan: The discourse on social security and the post-war construction of China. European Journal of East Asian Studies 11,2: 329-349.

Ma, Tehyun (2014) "The common aim of the Allied Powers": Social policy and international legitimacy in wartime China, 1940-47. Journal of Global History 9,2: 254-275.

MacKinnon, Stephen (2008) Wuhan, 1939: War, refugees, and the making of modern China. Berkeley: University of California Press.

Mao, Zedong (1940) On New Democracy. https://www.marxists.org/chinese/ maozedong/marxist.org-chinese-mao-194001.htm (retrieved 08 May 2020).

Mao, Zedong (1945) On Coalition Government. https:/www.marxists.org/ chinese/maozedong/marxist.org-chinese-mao-19450424.htm (retrieved 08 May 2020).

Mao, Zedong (1991) Organise up. In Selected works of Mao Zedong, vol. 3, ed. Mao Zedong, Beijing: People's Publisher, 933. 
Myers, Ramon H. (2000) The Chinese state during the Republican Era. In The modern Chinese state, ed. David Shamaugh, Cambridge: Cambridge University Press, 42-72.

Nanjing Archives (1947) 11-6504: Preparation Department for the Central Social Insurance Bureau of the Ministry of Social Affairs: Drafting social insurance principles.

Qin, Xiaoyi (ed.) (1983a) Revolutionary documents, vol. 96: Historical documents of the Resistance War against Japan and reconstruction-Social Reconstruction I. Taibei: Zhongyang wenwu gongyingshe.

Qin, Xiaoyi (ed.) (1983b) Revolutionary documents, vol. 97: Historical documents of the Resistance War against Japan and reconstruction-Social Reconstruction II. Taibei: Zhongyang wenwu gongyingshe.

Qin, Xiaoyi (ed.) (1983c) Revolutionary documents, vol. 99: Historical documents of the Resistance War against Japan and reconstruction-Social Reconstruction $I V$. Taibei: Zhongyang wenwu gongyinghshe.

Rodgers, Daniel (1998) Atlantic crossings: Social politics in a progressive age. Cambridge, MA: Harvard University Press.

Shi, Fuliang (1929) Outlines of social problems. Shanghai: Shanghai Nanqiang Publisher.

Shi, Fuliang (1930) The basics of social problems. Shanghai: New Life Publisher.

Shi, Shih-Jiunn (2017) Reviving the dragon: Social ideas and social policy development in Modern China. Issues \& Studies 53,3: 1-25.

Strauss, Julia C. (2000) The evolution of republican government. In Reappraising Republican China, ed. Frederic Wakeman, Jr and Richard L. Edmonds, New York: Oxford University Press, 75-97.

Sun, Benwen (2011) Sociology in contemporary China. Shanghai: Commercial Press. First published in 1948.

Sun, Hong and Deguang Bi (2018) Research on the social relief system of the Song Dynasty. Journal of Jingdezhen University 33,1: 64-68.

Sun, Yat-sen (1924) People's livelihood: Lectures I and II. In Lectures on three peoples' principles, see https://zh.wikisource.org/zh-hans/三民主义 (retrieved 08 May 2020).

Tang, Yuliang, Jilan Zhang, Yanping Cao, and Mingkui Liu (eds.) (2002) The working class and workers' movements in the anti-Japanese, democratic bases in the era of the resistance war against Japan, vol. 11 of The working class and workers' movements in Modern China, ed. Yuliang Tang and Mingkui Liu. Beijing: The CCP's Central Party School Publisher.

Tao, Menghe (1924) Social problems. Shanghai: Commercial Press. 
Tsin, Machael (1997) Imagining "society" in early twentieth-century China. In Imagining the people: Chinese intellectuals and the concept of citizenship, 1890-1920, ed. Joshua Fogel and Peter Zarrow. Armonk: M. E. Sharpe, 212-231.

Tsin, Machael (1999) Nation, governance, and modernity in China: Canton, 1900-1927. Stanford: Stanford University Press.

Tsui, Brian (2019) China's conservative revolution: The quest for a new order, 1927-1949. Cambridge: Cambridge University Press.

Van Slyke, Lyman P. (1967) Enemies and friends: The united front in Chinese communist history. Stanford: Stanford University Press.

Wakeman Jr., Frederic (2000) A revisionist view of the Nanjing Decade: Confucian fascism. In Reappraising Republican China, ed. Frederic Wakeman, Jr. and Richard L. Edmonds, New York: Oxford University Press, 141-178.

Wang, Junqiu (2008) Charity and relief in China. Beijing: Chinese Social Sciences Publisher.

Wang, Weiping (2002) On the primitive formation of Ancient China's social security system. Jianghai Academic Journal 5: 153-154.

Wang, Weiping (2007) On China's traditional social security affairs in ancient times. Study and Exploration serial no. 168: 232-236.

Will, Pierre-Etienne and R. Bin Wong (1991) Nourish the people: The state civilian granary system in China, 1650-1850. Ann Arbor: The University of Michigan.

Yan, Ming (2010) A history of China's sociology: A discipline and an era. Beijing: Qinghua University Press.

Yu, Boliu (1995) Zhongyong Suqu Jinji Shi. Nanchang: Jiangxi People’s Publisher.

Yue, Zongfu (2006) Social security legislation in Modern China, 1912-1949. Jinan: Qilu Book Publisher.

Zanasi, Margherita (2006) Saving the nation: Economic modernity in Republican China. Chicago: University of Chicago Press.

Zhang, Wen (2017) Inside and outside the system: The double-track system of social security in the Song Dynasty and its historical limitations. Chinese Social Security Review 1,4: 116-126.

Zhang, Younan and Wei Sun (2011) Research on the issue of labour laws in the Central Soviet Era. Jiangxi Social Sciences 3: 132-137.

Zhang, Zuping (2012) Research on the social security systems of the Ming-Qing era. Beijing: Beijing University Press.

Zhou, Xianwen (1944) Shou pin (Speaking of poverty). Dongfang Zazhi 40,12: 23-26. 
Zhou, Zhengben, Zhu Zhu, Shi Hua, Mingkui Liu, and Yuliang Tang (eds.) (2002) The working class and workers' movements in liberated areas during the Liberalisation War, vol. 14 of The working class and workers' movements in Modern China, ed. Yuliang Tang and Mingkui Liu. Beijing: The CCP's Central Party School Publisher.

Zhu, Yisong (1933) Social policy. Shanghai: Commercial Publisher.

Open Access This chapter is licensed under the terms of the Creative Commons Attribution 4.0 International License (http://creativecommons.org/licenses/ by/4.0/), which permits use, sharing, adaptation, distribution and reproduction in any medium or format, as long as you give appropriate credit to the original author(s) and the source, provide a link to the Creative Commons licence and indicate if changes were made.

The images or other third party material in this chapter are included in the chapter's Creative Commons licence, unless indicated otherwise in a credit line to the material. If material is not included in the chapter's Creative Commons licence and your intended use is not permitted by statutory regulation or exceeds the permitted use, you will need to obtain permission directly from the copyright holder.

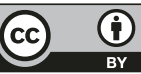

